\title{
Succulence and CAM relationships in Aeonium genus
}

\author{
M.S. JIMENEZ, D. MORALES, J. IRIARTE and F. GIL. \\ Departmento de Fisiologia Vegetal. Facultad de Farmacia. Universidad de la Laguna. \\ Islas Canarias. Spain.
}

(Received 23 February 1982; in revised form 17 June 1982)

Key words: Aeonium, CAM, cell structure, Sm index, succulence.

\begin{abstract}
The CAM has been tested in six species of the Aeonium genus by studying the diurnal fluctuation of organic acids, $\mathrm{pH}$ and night fixation of $\mathrm{CO}_{2}$. The existence of a mesophyll structure able to support this metabolism has been shown as well as a congruent periodicity in the pool of cell starch.

We have calculated the $\mathrm{S}$, ES and $\mathrm{Sm}$ indices in the six species. A series of regression equations of different grades and types were calculated and shown to have correlation coefficients statistically significant. This allows us to confirm the suitability of the Sm index as a rapid test to establish the CAM as postulated by former authors.
\end{abstract}

Resumen. Se ha comprobado el CAM en seis especies del género Aeonium, mediante el estudio de las fluctuaciones diurnas del acervo de ácidos orgánicos, de las oscilaciones periódicas de $\mathrm{pH}$ y de la captura nocturna de $\mathrm{CO}_{2}$, al mismo tiempo que se ha verificado en ellas le existencia de una estructura del mesófilo capaz de soportar este metabolismo y una periodicidad congruente en el acervo de almidón celular.

Se han calculado asimismo los índices S, ES y Sm de especímenes de las seis especies y se ha podido establecer una serie de ecuaciones de regresión de distinto tipo y grado, a unos niveles de significación, que permiten postular, en el citado material, la idoneidad del indice $\mathrm{Sm}$ como prueba rápida del metabolismo ácido de las crasuláceas, confirmando de este modo las teorías de los primeros autores.

\section{Introduction}

The determination of CAM in different plant species has been made according to various physical, biochemical, enzymatic, physiological and morphological criteria, among which we could mention dark $\mathrm{CO}_{2}$ fixation, nocturnal acidification, $\delta^{13} \mathrm{C}$ values, dark malate synthesis, diurnal carbohydrate fluctuation, enzyme assays, dark stomatal opening, deuterium content ( $\delta \mathrm{D}$ values) and succulence.

As far as succulence is concerned there exists non-succulent plants which show CAM $[6,7,16,11,15,17]$ and succulent plants which do not show it [12]. According to Kluge and Ting [12] the succulent plants which do not show an assimilatory storing water tissue have to be considered as non-CAM plants, since only the succulent plants which have the sources, the storing areas and the acid sinks in the same cells can perform the whole of the CAM pathway. Having those facts in view, anatomical studies of succulent plants were needed as the first approach to show the existence of this metabolism. 
The aim of the present paper is to determine the relationships between the succulence structure and CAM.

\section{Material and methods}

The research was performed on six species of the Aeonium genus (Crassulaceae family) not included until now in the list of CAM species $[2,30,29]$, but which presumably could show the character because they belong to such a family and that one species of this genus ( $A$. havorthii) is already known as CAM plant [19].

The chosen species were $A$. canariense (L.) Webb et Berth., $A$. urbicum (Chr. Sm. ex Buch) Webb et Berth., $A$. lindleyi Webb et Berth., $A$. tabulaeforme (Haw) Webb et Bert., A. spathulatum (Hornem.) Praeger and $A$. ciliatum (Willd) Webb et Berth. The last one in the list was already studied with regard to the $\delta{ }^{13} \mathrm{C}$ and $\delta \mathrm{D}$ values [35].

The plants were cultivated in pots containing a natural substratum maintained at $\psi_{\mathrm{w}}^{\mathrm{s}}$ (soil water potential) of approximately -1 bar, by controlled irrigation through a Czeratzki tensiometer. They were placed, in spring, in natural environments (relative humidity variable between 35 and $85 \%$, minimum mean night temperature of $13.5^{\circ} \mathrm{C}$, maximum mean day temperature of $30^{\circ} \mathrm{C}$ and maximum mean irradiance of $41 \mathrm{~W} \mathrm{~m}^{-2}$.

\section{Determination of CAM}

Twice a day ( $9 \mathrm{a} . \mathrm{m}$. and $7 \mathrm{p} . \mathrm{m}$.) three samples in similar position on the plant, were taken from each species for the following determinations: $\mathrm{pH}$ measurements at 0.01 unit, rates of dark $\mathrm{CO}_{2}$ uptake in confined environment through variations of the $\mathrm{NaHCO}_{3} 5 \times 10^{-5} \mathrm{~N}$ buffer system [24] in $300 \mathrm{~cm}^{3}$ flasks and acid titrations to a $\mathrm{pH} 7.00$ end point $[9,31]$ with $0.01 \mathrm{~N} \mathrm{NaOH}$ (data expressed as $\mu \mathrm{eg} / \mathrm{g}$ fresh weight). The $\mathrm{pH}$ end point used is halfway between the most habitual in the bibliography $[27,3,5$, $14,13,26,33,22]$. The mean values $(n=6)$ of the three samples are presented in this paper, except for regressions calculations where all the values were used in order to obtain more degrees of freedom $(n=18)$.

\section{Succulence evaluation}

Succulence was evaluated by the following indices: surface expansion (ES) [32], degree of succulence (S) [8] and mesophyll succulence (Sm) [12]. A variable number of basal leaves according to the foliar size of the specimens were used for each determination of succulence. The foliar surfaces were determined by weighing outlines of millimeter paper and application of spatial geometrical factors of correction determined by the differences between the weighing of the leaves after water spraying and keeping in darkness for 24 hours at $4{ }^{\circ} \mathrm{C}$ and their weights after drying 24 hours at $105^{\circ} \mathrm{C}$. The chlorophyll content was obtained by the method of Richards and Thompson [23]. 


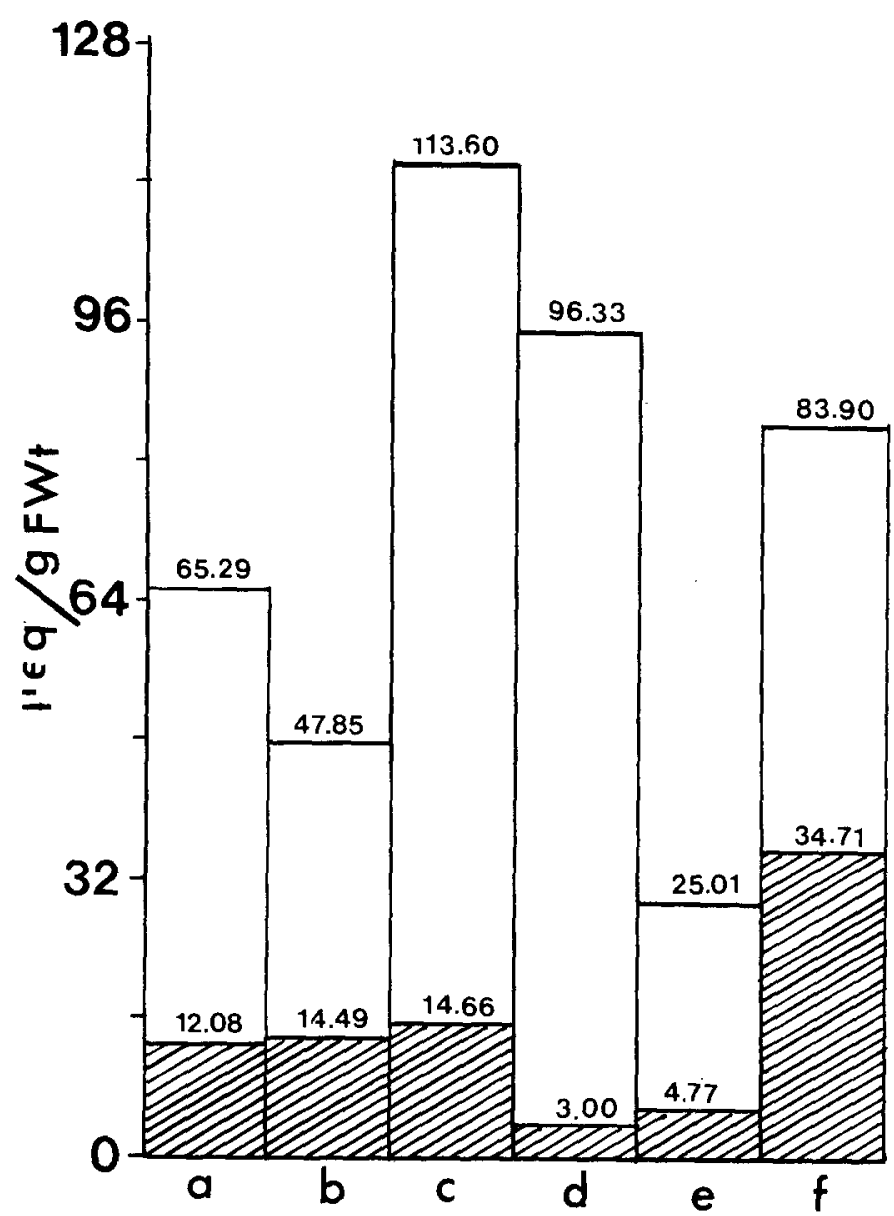

Figure 1. Diurnal fluctuations of organic acids (white areas), acidity at 7 p.m. (shaded areas) and acidity at 9 a.m. (total areas) in a: $A$. canariense, b: $A$. ciliatum, c: $A$ : urbicum, d: A. lindleyi, e: $A$. tabulaeforme and f: $A$. spathulatum.

\section{Cell structure determination}

Leaves of the different species were fixed according to the usual techniques of light microscopy (fixation with FAA, inclusion in paraffin and dyeing with safranin-fast green). Starch fluctuations were observed in samples taken at sunset and sunrise and stained with potassium iodide-iodine (IKI), contrasting with fast green.

\section{Results and discussion}

a) Diurnal fluctuation of organic acids and of $\mathrm{pH}$

All the species showed a nocturnal increase in acidity (Fig. 1) with values of 53.21 (A. canariense), 33.36 (A. ciliatum), 98.94 (A. urbicum), 93.33 


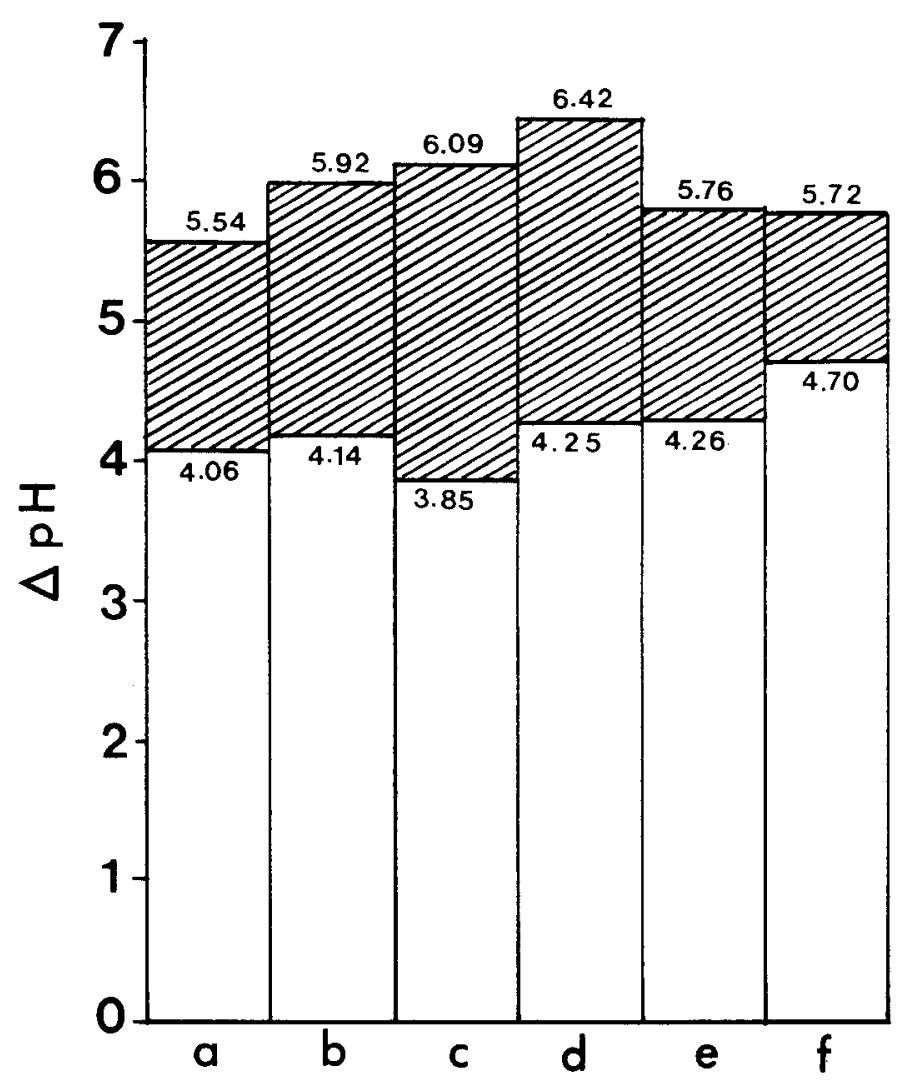

Figure 2. $\mathrm{pH}$ increment (shaded areas), values of $\mathrm{pH}$ at $7 \mathrm{p.m}$. (total areas) and values of $\mathrm{pH}$ at 9 a.m. (white areas) in the six species.

(A. lindleyi), 20.24 (A. tabulaeforme) and $49.19 \mu \mathrm{eg} / \mathrm{g}$ fresh weight $(A$. spathulatum). These values are not as high as the ones obtained by Heyne (10) and many others, probably by the low $\mathrm{pH}$ end point used, but they are in the rank established by Milburn et al. [18] and they agree with the data found in other species of the same family which manifest CAM [27].

In accordance with the acid fluctuation, $\mathrm{pH}$ oscillations were observed in the cell extracts (Fig. 2). The positive correlation between the $\mathrm{pH}$ fluctuations and the diurnal oscillations of titratable acidity is statistically significant at 0.05 level $(r=0.68)$ in spite of the different vacuole magnitude of the involved cells and their different buffering capacity.

b) Dark $\mathrm{CO}_{2}$ uptake.

In all the species, a dark $\mathrm{CO}_{2}$ uptake was detected (Fig. 3). Its amplitude was not comparable to that showed in Agave [20], in Prenia and Sempervivum [1] and in pineapple $[19,25]$. But our measurements were made in hermetic flasks of limited volume, and so the $\mathrm{CO}_{2}$ fixation by the leaves 


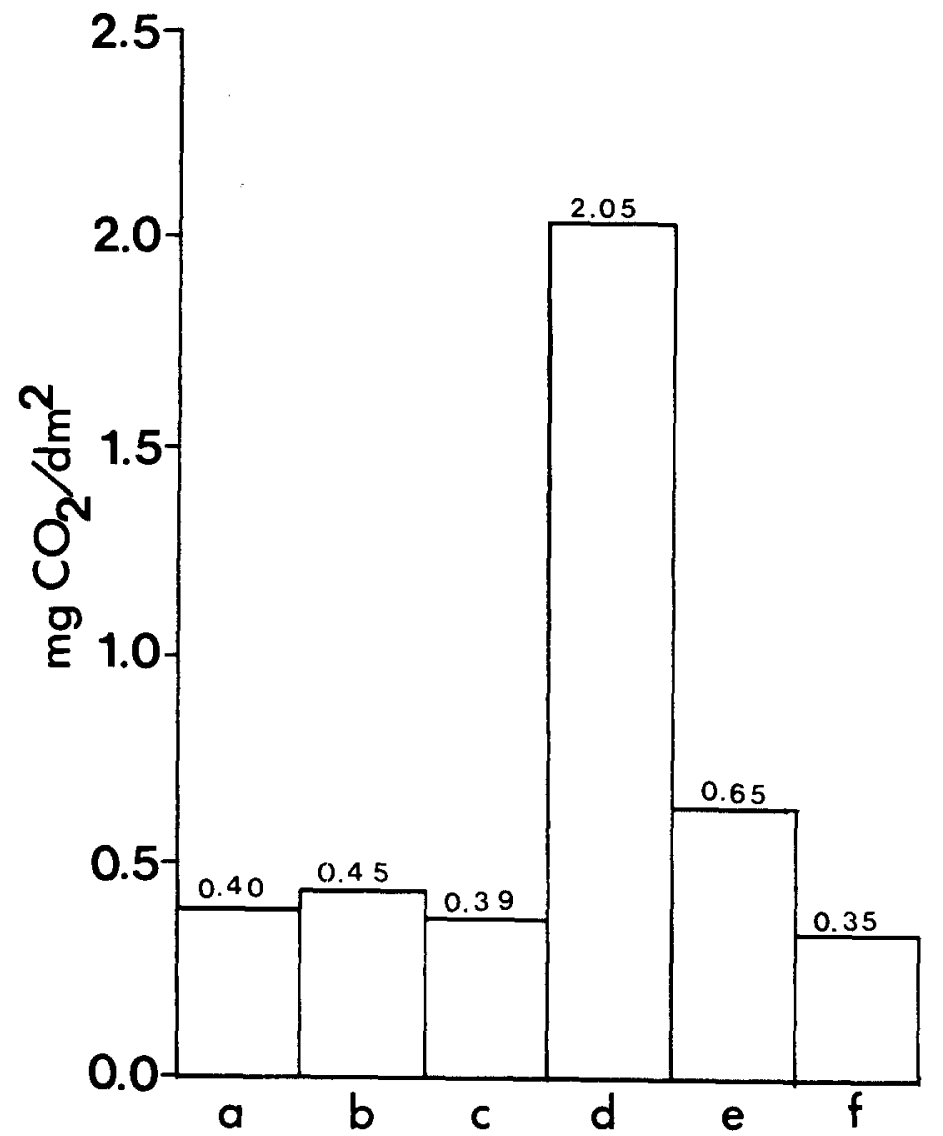

Figure 3. Night $\mathrm{CO}_{2}$ uptake in confined environment in the different species of Aeonium genus.

quickly reduced the gas concentration in the chamber resulting in an underestimation of the dark $\mathrm{CO}_{2}$ fixation.

c) Mesophyll structure.

As with former studies [4] all the species investigated showed a unique type of photosynthetic parenchyma with cells possessing a big central vacuole surrounded by a thin layer of cytoplasm containing the metaplasmatic structures (Plate 1-A), without showing in any circumstance a differentiation in assimilatory water storing parenchyma. A considerable difference in starch content was observed between samples at sunset and sunrise (Plate $1-\mathrm{B}$ and 1-C). It is known that there is an inverse relationship between the acid synthesis and the storage of starch and other carbohydrates [34, 21, $28]$. We can conclude that the six studied species, at least under our testing conditions, showed the CAM character. 


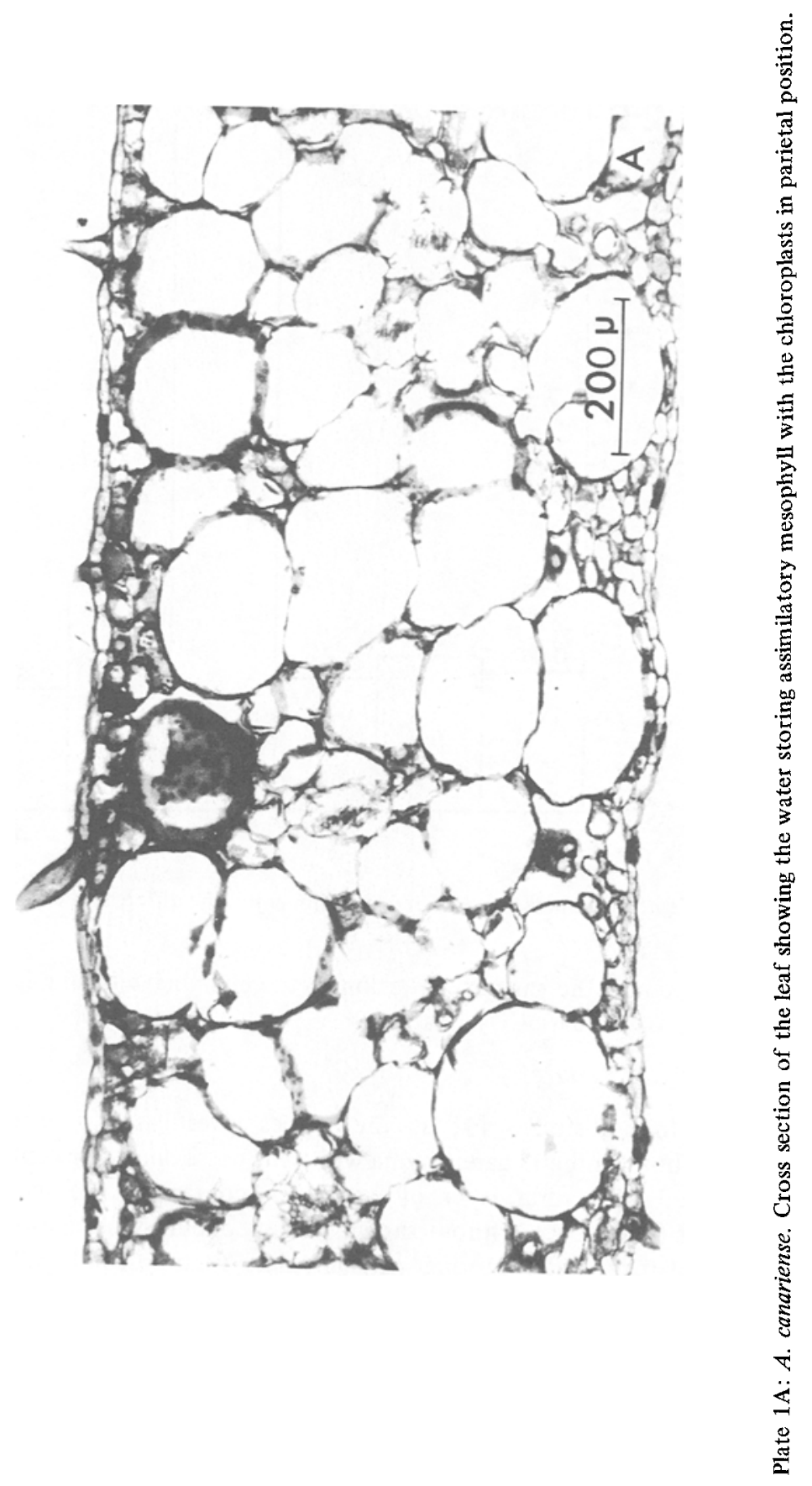




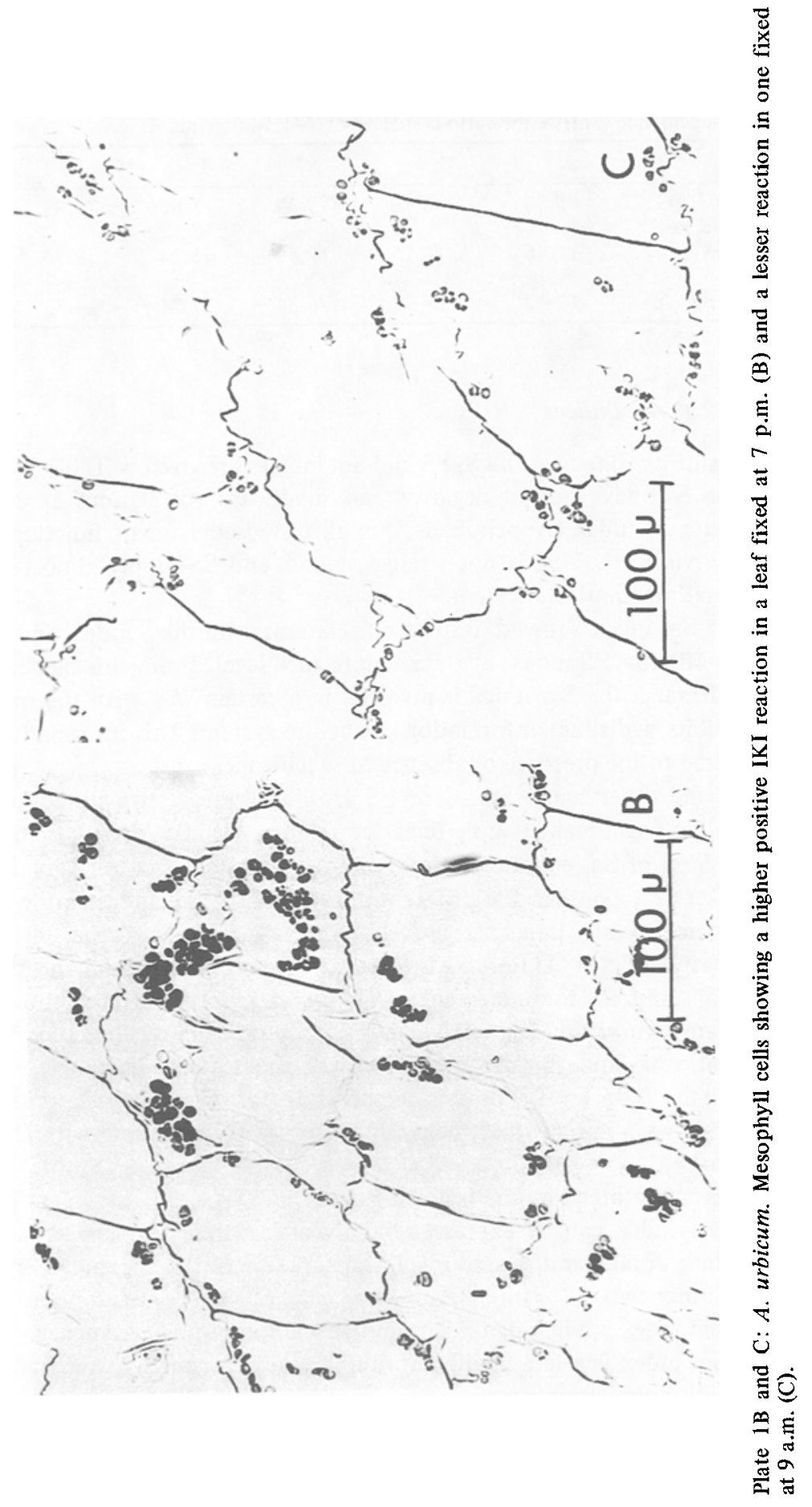


Table 1. Indices values: surface expansion (ES), degree of succulence (S) and mesophyll succulence $(\mathrm{Sm})$ in the various species of Aeonium genus

\begin{tabular}{lrrrrrr}
\hline & \multicolumn{1}{c}{$\mathrm{a}$} & \multicolumn{1}{c}{$\mathrm{b}$} & \multicolumn{1}{c}{$\mathrm{c}$} & $\mathrm{d}$ & \multicolumn{1}{c}{$\mathrm{e}$} & \multicolumn{1}{c}{$\mathrm{f}$} \\
\hline $\mathrm{ES}\left(\mathrm{cm}^{2} / \mathrm{g}\right)$ & 5.86 & 6.72 & 9.39 & 5.63 & 11.83 & 34.17 \\
$\mathrm{~S}\left(\mathrm{~g} / \mathrm{dm}^{2}\right)$ & 17.46 & 14.15 & 10.40 & 18.24 & 8.75 & 3.20 \\
$\mathrm{Sm}(\mathrm{g} / \mathrm{mg} \mathrm{ch1})$ & 12.42 & 8.98 & 6.34 & 21.74 & 14.83 & 1.43 \\
\hline
\end{tabular}

\section{d) Succulence indices}

The value obtained for the S, ES and Sm indices are given in Table 1 .

The $S$ index showed negative and significant correlations at 0.05 level with the Es index (Appendix $1^{\circ}$ ), in all tested adjustment functions (linear and curvilinear). This is not strange since $S$ and ES supply almost identical information about the system.

The Sm index showed positive correlations with the $S$ index, and negative ones with the ES index, at 0.05 significance level. From this fact it follows that although the Sm index is involved in a certain way with the other two, it exhibits a distinct information about the system. This information is not restricted to the presence or absence of succulence.

On the other hand, Sm, S or ES are double regressive functions of the other two (significant double linear correlation at 0.05 level) but the significance level of $\mathrm{Sm}$ equation is inferior to the $\mathrm{S}$ and ES ones (Appendix $2^{\circ}$ ). This fact may confirm the different purpose of the Sm and the other indices.

The acidity at $7 \mathrm{p} . \mathrm{m}$. is negatively correlated with $\mathrm{Sm}$ for all tested functions (Appendix $3^{\circ}$ ). For the acidity at $9 \mathrm{a} . \mathrm{m}$. the parabolic and the cubic function, and for the increment of nocturnal acidity, only the cubic adjustment are significant. For $\mathrm{pH}$ values at $7 \mathrm{p} . \mathrm{m}$. and $9 \mathrm{a} . \mathrm{m}$. the cubic function is significant, and for $\mathrm{pH}$ oscillations all the tested adjustment equations exceed the 0.05 level. For this reason it is possible to deduce that the Sm index shows a major adjustment with acidity at 7 p.m. and with $\mathrm{CO}_{2}$ dark uptake.

This is reinforced by the following facts:

a) $\mathrm{Sm}$ index can be expressed validly as a simple regressive function of $\mathrm{CO}_{2}$ dark uptake and as a double linear function of this parameter and either of the other two.

b) $\mathrm{Sm}$ index is a less significant linear function of $\mathrm{pH}$ increment.

c) Sm index is a less significant double linear function of $\mathrm{pH}$ fluctuations and acidity oscillations.

d) Sm index is not a significant simple function of the organic acids increment.

In this respect we can not forget that $\mathrm{CO}_{2}$ dark uptake is, among the three parameters, the best connected with the CAM, since it is possible to observe 
daily acidity fluctuations in $\mathrm{C}_{3}$ plants similar to the ones obtained in the CAM plants [22].

The triple correlation of the $\mathrm{Sm}$ index with the three considered parameters.

$\mathrm{Sm}=-0.11 \mu \mathrm{eg} / \mathrm{g}$ fresh $\mathrm{wt}+5.86 \Delta \mathrm{pH}+9.05 \mathrm{mg} \mathrm{CO}_{2} / \mathrm{dm}^{2}+1.00$ is significant at 0.001 level $(r=0.89)$; for this fact we can affirm that the $\mathrm{Sm}$ index is a valuable quick criterion to establish the CAM character, although it is evident that the whole guarantee of diagnosis will only be obtained with the maximum number of in dividual criteria.

For the former equation it is implied that an ideal non-CAM plant, in which the three parameters are assumed equal to zero, $\mathrm{Sm}=1.00$ will be verified, which agrees with the obtained values (12) in several non-CAM and CAM species, which give a mean Sm value of $0.59(n=9)$ for the former and $\mathrm{Sm}=4.68(\mathrm{n}=7)$ for the latter ones, with respective maximums and minimums of 1.25 and 0.346 (non-CAM) and of 13.00 and 1.34 (CAM).

Therefore, for the six studied species of the Aeonium genus which proved to show CAM, the $\mathrm{Sm}$ index, with a mean value of $\mathrm{Sm}=10.96$, Sm maximum $=21.74$ and $\mathrm{Sm}$ minimum $=1.43$, comes to be a valid test, which shows a greater information quantity for this purpose than the $S$ and ES indices, which makes evident the greater diagnosis importance of the nocturnal gaseous exchange than the acidity fluctuations one and which characterizes the acid metabolism of the Crassulaceae. This result can be applied, perhaps, to other genus and species, because of its special significance level.

\section{References}

1. André M, Thomas DA, von Willert DJ and Gerbaud A (1979) Oxygen and carbon dioxide exchanges in Crassulacean-acid-metabolism-plants. Planta 147:141-144

2. Black CC and Williams S (1976) Plants exhibiting characteristics common to Crassulacean Acid Metabolism. In Burris $\mathrm{RH}$ and Black $\mathrm{CC}$ eds. $\mathrm{CO}_{2}$ metabolism and plant productivity pp 407-424

3. Bloom AJ (1979) Salt requirement for Crassulacean Acid Metabolism in the annual succulent Mesembryanthemum crystallinum. Plant Physiol. 63:749-753

4. Caballero A and Jiménez MS (1977) Contribución al estudio anatómico foliar de las crasuláceas canarias. Vieraea 7:115-132

5. Cockburn W (1979) Relationships between stomatal behavior and internal carbon dioxide concentration in Crassulacean Acid Metabolism Plants. Plant Physiol 63:1029-1032

6. Coutinho LM (1963) Algumas informacoes sobre a occurrencia do "effeito de De Saussure" em epifitas e erbaceas terrestres de mata pluvial. Botanica 20:83-98

7. Coutinho LM (1969) Novas observacoes sobre a ocurrencia do "efeito de De Saussure" e suas relaçoes com a susulencia, a temperatura folhear e os movimentos estomaticos. Botanica 24:77-102

8. Delf EM (1912) Transpiration in succulent plants. Ann. Bot. 26:409-440

9. Hanscom $Z$ and Ting IP (1978) Responses of succulents to Plant Water Stress. Plant Physiol. 61:327-330

10. Heyne B (1815) On the deoxidation of the leaves of Cotyledon calycina. Trans. Linn. Soc. Lond. 11 (II) $: 213-215$

11. Kluge M, Lange OL, von Eichmann M and Schmidt R (1973) Diurnaler Saurerhythmus bei Tillandsia usneoides: Untersuchungen über den Weg des Kohlenstoffs 
sowie die Abhangigkeit des $\mathrm{CO}_{2}$-Gaswechsels von Lichtintensitat, Temperatur und Wassergehalt der Pflanze. Planta 112:357-372

12. Kluge M and Ting IP (1978) Crassulacean Acid Metabolism. Analysis of an Ecological Adaptation. Springer Verlag. New York Berlin Heidelberg pp. 209

13. Koch K and Kennedy RA (1980) Characteristics of Crassulacean Acid Metabolism in the succulent $\mathrm{C}_{4}$ Dicot, Portulaca oleracea L. Plant Physiol. 65:193-197

14. Lattge $U$ and Ball $E$ (1979) Electrochemical investigation of active malic acid transport at the tonoplast into the vacuoles of the CAM plant Kalanchoe daigremontiana. J. Membrane Biol. 47:401-422

15. Madhusadana Rao I, Swamy PM and Das VSR (1977) CAM syndrome in some nonsucculents and its inhibition by paraquot. Abstracts of 4 th. Int. Congress on Photosynthesis ISBN 0-904963-17-9

16. McWilliams EL (1970) Comparative rates of dark $\mathrm{CO}_{2}$ uptake and acidification in the Bromeliaceae, Orchidaceae and Euphorbiaceae. Bot. Gaz. 131:285-290

17. Medina $\mathrm{E}$ and Troughton JH (1974) Dark $\mathrm{CO}_{2}$ fixation and the carbon isotope ratio in Bromeliaceae. Plant Sci. Lett. 2:357-362

18. Milburn TR, Pearson DJ and Ndegwe NA (1968) Crassulacean Acid Metabolism under natural tropical conditions. New Phytol. 67:883-897

19. Neales TF, Patterson AA and Hartney VJ (1968) Physiological adaptation to drought in the carbon assimilation and water loss of xerophy tes. Nature 219:469472

20. Nobel PS and Hartsock TL (1979) Environmental influences on open stinatas if a Crassulacean Acid Metabolism plant, Agave deserti. Plant Physiol. 63:63-66

21. Ranson SL and Thomas M (1960) Crassulacean Acid Metabolism. Ann. Rev. Plant Physiol. 11:81-110

22. Rayder $\mathrm{L}$ and Ting IP (1981) Carbon metabolism in two species of Pereskia (Cactaceae). Plant Physiol. 68:139-142

23. Richards FA and Thompson TG (1952) The estimation and characterization of plankton population by pigments analyses. II. A spectrophotometric method for the estimation of plankton pigments. J. Mar. Res. 11:156-172

24. Ross CW (1974) Plant Physiology laboratory manual. Wadsworth Pub. Co. Inc. Belmont. pp 200

25. Sale PJM and Neales TF (1980) Carbon Dioxide assimilation by Pineapple Plants, Ananas comosus (L.) Merr. I. Effects of Daily Irradiance. Aust. J. Plant Physiol. $7: 363-373$

26. Seeni S and Gnanam A (1980) Photosynthesis in cell suspension cultures of the CAM plant Chamaecereus sylvestrii (Cactaceae). Physiol. Plant. 49:465-472

27. Spalding MH and Edwards GE (1978) Photosynthesis in Enzymatically Isolated Leaf Cells from the CAM Plant Sedum telephium L. Planta 141:59-63

28. Sutton BG (1975) The path of carbon in CAM plants at night. Aust. J. Plant Physiol. 2:377-388

29. Szarke SR (1979) The Occurrence of Crassulacean Acid Metabolism: A Supplementary List During 1976 to 1979. Photosynthetica. 13:467-473

30. Szarek SR and Ting IP (1977) The occurrence of Crassulacean Acid Metabolism among plants. Photosynthetica 11:330-342

31. Ting IP (1981) Effects of abscisicid on CAM in Portulacaria afra. Photosynthesis Research. 2:39-48

32. Walter H (1926) Die Anpassungen der Pflanzen an Wassermangel: Das Xerophytenproblem in kausal-physiologischer Betrachtung. Naturwissenschaft und Landwirtschaft, Heft 9. Freising-Munchen: Verlag Dr. F.P. Da Herer u. Cie.

33. Winter $\mathrm{K}$ (1980) Carbon dioxide and water vapor exchange in the Crassulacean Acid Metabolism Plant Kalanchoè pinnata during a prolonged light period. Plant Physiol. 66:917-921

34. Wolf J (1960) Der diurnale Saurerhythmus. In Ruhland W ed. Encyclopedia of Plant Physiology, pp 809-889. Springer Verlag. Berlin Heidelberg New York

35. Ziegler $\mathrm{H}$ von (1979) Diskriminierung von Kohlenstoff- und Wasserstoffisotopen: Zusammenhänge mit dem Photosynthese-mechanismus und den Standortbedingungen. Ber. Deutsch. Bot. Ges. Bd. 92:169-184 


\section{Appendix}

$1^{\circ}$. - Significant reciprocal equations (linear, exponential, logarithmic, power, parabolic and cubic curves) and correlation coefficients (I) of the S, ES and Sm indices.

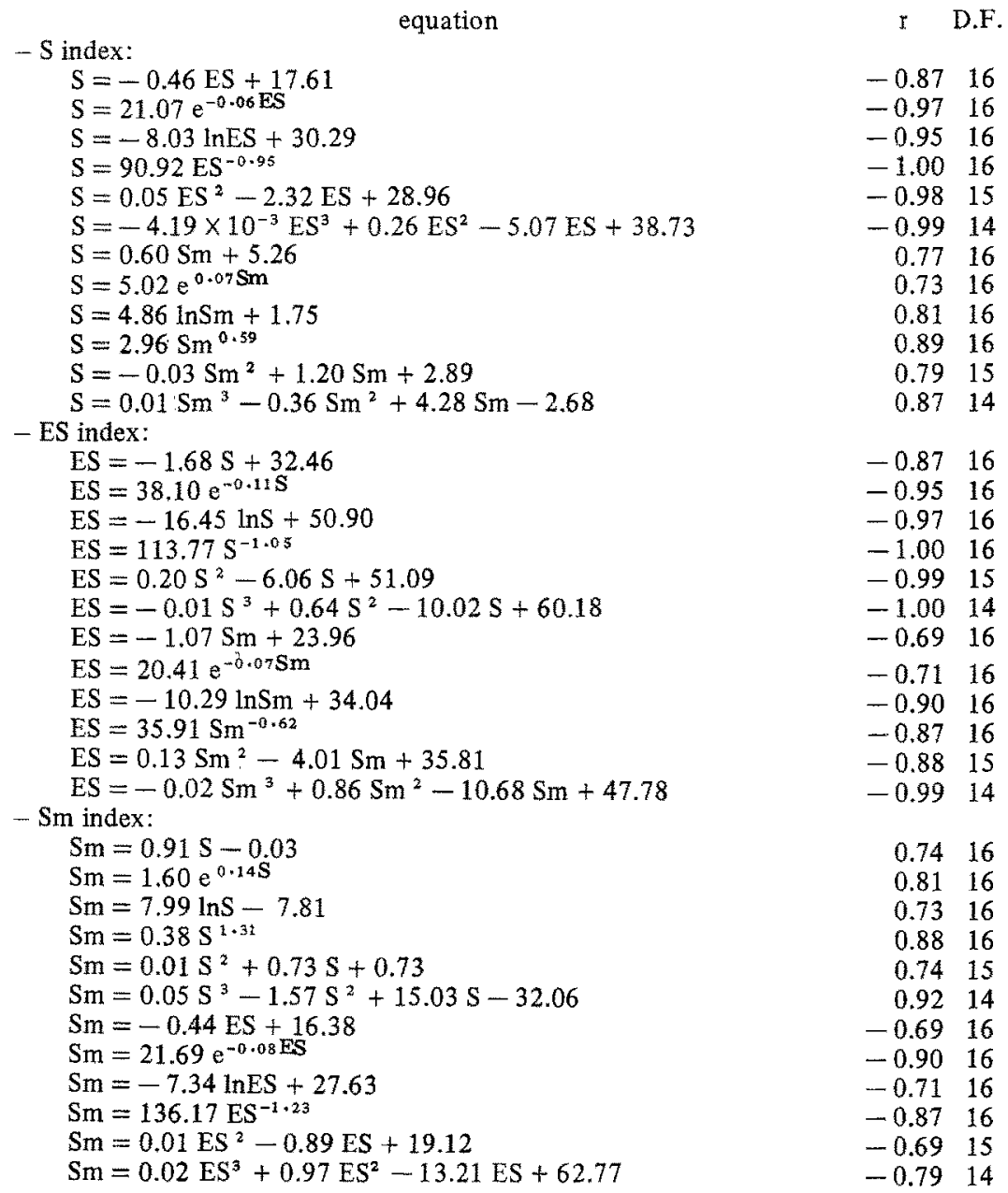

$2^{\circ}$. - Significant double linear equations and correlation coefficients of the three indices in function of the other two.

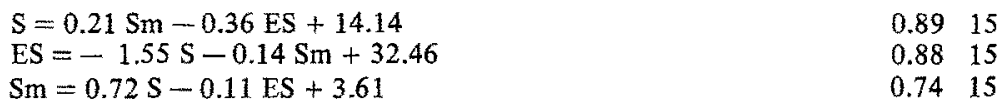

$3^{\circ}$. - Significant reciprocal equations (linear, exponential, logarithmic, power, parabolic and cubic curves) and correlation coefficients between $\mathrm{Sm}$ index and acidity and $\mathrm{pH}$ oscillations and dark $\mathrm{CO}_{2}$ uptake in confined environment. 
- Acidity at 7 p.m.

$\mu \mathrm{eq} / \mathrm{g} \mathrm{Fwt}_{19}=-1.43 \mathrm{Sm}+29.66$

$\mu \mathrm{eq} / \mathrm{g} \mathrm{Fwt}_{19}=38.62 \mathrm{e}^{-0.12 \mathrm{Sm}}$

$\mu \mathrm{eq} / \mathrm{g} \mathrm{Fwt} \mathrm{t}_{19}=-11.58 \operatorname{lnSm}+38.45$

$\mu \mathrm{eq} / \mathrm{g} \mathrm{FWt}_{19}=59.07 \mathrm{Sm}^{-0.82}$

$\mu \mathrm{eq} / \mathrm{g} \mathrm{Fwt}_{19}=0.08 \mathrm{Sm}^{2}-3.40 \mathrm{Sm}+37.56$

$\mu \mathrm{eq} / \mathrm{g} \mathrm{Fwt}_{19}=-0.01 \mathrm{Sm}^{3}+0.26 \mathrm{Sm}^{2}-4.94 \mathrm{Sm}+40.74$

- Acidity at 9 a.m.:

$\mu \mathrm{eq} / \mathrm{g} \mathrm{FWt}_{9}=0.36 \mathrm{Sm}^{2}-9.18 \mathrm{Sm}+114.10$

$\mu \mathrm{eq} / \mathrm{g} \mathrm{Fwt}_{9}=0.08 \mathrm{Sm}^{3}-2.51 \mathrm{Sm}^{2}+16.81 \mathrm{Sm}+67.48$

$-0.89 \quad 16$

$-0.9616$

$-0.98 \quad 16$

$-0.8916$

$-0.9615$

$-0.9814$

Increment of nocturnal acidity:

$\Delta \mu \mathrm{eq} / \mathrm{g} \mathrm{Fwt}=0.09 \mathrm{Sm}^{3}-2.83 \mathrm{Sm}^{2}+22.34 \mathrm{Sm}+26.09$

$-0.57 \quad 15$

$-0.8114$

$-\mathrm{pH}$ at 7 p.m.:

$\mathrm{pH}_{19}=6.60 \times 10^{-4} \mathrm{Sm}^{3}-0.02 \mathrm{Sm}^{2}+0.17 \mathrm{Sm}+5.52 \quad 0.5414$

$-\mathrm{pH}$ at 9 a.m.:

$\mathrm{pH}_{9}=-7.14 \times 10^{-4} \mathrm{Sm}^{3}+0.03 \mathrm{Sm}^{2}-0.33 \mathrm{Sm}+5.09 \quad-0.5714$

- Nocturnal increment of $\mathrm{pH}$ :

$\Delta \mathrm{pH}=0.02 \mathrm{Sm}+1.29$

$\Delta \mathrm{pH}=1.29 \mathrm{e}^{0.02 \mathrm{Sm}}$

$\Delta \mathrm{pH}=0.29 \operatorname{lnSm}+1.09$

$\Delta \mathrm{pH}=1.06 \mathrm{Sm}^{0.21}$

$\Delta \mathrm{pH}=-8.84 \times 10^{-4} \mathrm{Sm}^{2}+0.05 \mathrm{Sm}+1.27$

$\Delta \mathrm{pH}=1.54 \times 10^{-3} \mathrm{Sm}^{3}-0.05 \mathrm{Sm}^{2}+0.54 \mathrm{Sm}+0.40$

$0.79 \quad 14$

$0.47 \quad 16$

0.5216

$0.57 \quad 16$

0.6616

$0.48 \quad 15$

0.8914

- Dark $\mathrm{CO}_{2}$ uptake

$\mathrm{mg} \mathrm{CO} / \mathrm{dm}^{2}=0.08 \mathrm{Sm}-0.13$

$\mathrm{mg} \mathrm{CO} / \mathrm{dm}^{2}=0.22 \mathrm{e}^{0.08 \mathrm{Sm}}$

0.8216

0.8716

$\mathrm{mg} \mathrm{CO} / \mathrm{dm}^{2}=0.40 \operatorname{lnSm}-0.13$

0.5716

$0.66 \quad 16$

$\mathrm{mg} \mathrm{CO} / \mathrm{dm}^{2} \doteq 0.21 \mathrm{Sm}^{0.46}$

$0.97 \quad 15$

$\mathrm{g} \mathrm{CO}_{2} / \mathrm{dm}^{2}=0.01 \mathrm{Sm}^{2}-0.09 \mathrm{Sm}+0.55$

$0.98 \quad 14$

$4^{\circ}$. - Significant single and double linear equations and correlation coefficients of $\mathrm{Sn}$ index in function of acidity and $\mathrm{pH}$ oscillations and of dark $\mathrm{CO}_{2}$ uptake in confine environment.

$\mathrm{Sm}=6.94 \Delta \mathrm{pH}-0.83$

$0.47 \quad 16$

$\mathrm{Sm}=8.69 \mathrm{mg} \mathrm{CO} / \mathrm{dm}^{2}+4.77$

0.8216

$\mathrm{Sm}=-0.11 \Delta \mu \mathrm{eq} / \mathrm{g} \mathrm{Fwt}+10.89 \Delta \mathrm{pH}-1.66$

0.6215

$\mathrm{Sm}=9.99 \mathrm{mg} \mathrm{CO} 2 / \mathrm{dm}^{2}-0.06 \Delta \mu \mathrm{eq} / \mathrm{g} \mathrm{Fwt}+7.33$

0.8515

$\mathrm{Sm}=1.38 \Delta \mathrm{pH}+8.22 \mathrm{mg} \mathrm{CO} / \mathrm{dm}^{2}+2.77$

$0.82 \quad 15$ 